\title{
PERANCANGAN SISTEM PEMENUHAN TENAGA KERJA RUMAH SAKIT MENGGUNAKAN METODE WISN DAN PROMETHEE II
}

\section{HOSPITAL LABOR FULFILLMENT DESIGN SYSTEM USING WISN AND PROMETHEE II}

\author{
Dani Ahmad Jamaluddin ${ }^{1)}$, Latifah Rifani ${ }^{2)}$ \\ 1) Program Studi Sistem Informasi, Fakultas Ilmu Komputer, Universitas Narotama \\ 2) Program Studi Teknik Informatika, Fakultas Ilmu Komputer, Universitas Narotama \\ Jl Raya Arief Rachman Hakim No 51, Surabaya \\ Email : daniahmadj98@gmail.com ${ }^{1)}$, latifahrifani@gmail.com ${ }^{2)}$
}

\begin{abstract}
Abstrak
Pandemi covid 19 yang terjadi di Indonesia pada saat ini, membuat beberapa pelayanan kesehatan khususnya rumah sakit mengalami kewalahan dalam menghadapi lonjakan pasien yang mengakibatkan keterlambatan pelayanan kesehatan. Penelitian ini bertujuan untuk membuat perancangan sistem yang dapat membantu memaksimalkan pemenuhan tenaga kerja menjadi lebih efisien dan efektif untuk mempercepat proses pelayanan kesehatan di rumah sakit. Untuk melakukan perhitungan kebutuhan tenaga kerja, peneliti menerapkan metode WISN (Workload Indicator Staff Need) dan metode PROMETHEE II sebagai pembobotan calon tenaga kerja. Penelitian ini mengambil studi kasus pada Rumah Sakit Ibu dan Anak Nur Ummi Numbi (RSIA NUN) Surabaya, yakni pada instalasi farmasi dan instalasi laboratorium. Penerimaan tenaga kerja menggunakan 5 kriteria sebagai pembobotan yakni pengalaman kerja, pendidikan terakhir, hasil test tulis, hasil interview, dan test kesehatan. Proses bisnis yang dibuat mulai dari pengguna memasukkan data beban kerja yang kemudian dilakukan perhitungan kebutuhan tenaga kerja oleh sistem. Hingga calon tenaga kerja melakukan pendaftaran yang kemudian dilakukan pembobotan oleh sistem. Perancangan yang telah dibuat selanjutnya dilakukan evaluasi menggunakan metode heuristic evaluation, dengan hasil pada masing-masing aspek berskala 0 dan tidak ditemukan adanya permasalahan pada usability, sehingga perancangan yang telah dibuat, dapat dibangun sebuah sistem pendukung keputusan sesuai dengan perancangan yang telah dibuat.
\end{abstract}

Kata kunci: Covid-19, Rumah sakit, WISN, PROMETHEE II, Tenaga Kerja

Abstract

The COVID-19 pandemic that is happening in Indonesia at this time has made several health services, especially hospitals, overwhelmed in dealing with a surge in patients which resulted in delays in health services. This study aims to design a system that can help maximize the fulfillment of the workforce to be more efficient and effective to accelerate the process of health services in hospitals. To calculate the workforce needs, the researchers applied the WISN (Workload Indicator Staff Need) method and the PROMETHEE II method as weighting for prospective workers. This study took a case study at the Nur Ummi Numbi Mother and Child Hospital (RSIA NUN) Surabaya, namely the pharmaceutical installation and laboratory installation. Employment acceptance uses 5 criteria as a weighting, namely work experience, latest education, written test results, interview results, and health tests. Business processes are created starting from the user entering workload data which is then calculated by the system for manpower requirements. Until prospective workers register, which is then weighted by the system. The design that has been made is then evaluated using the heuristic evaluation method, with the results on each aspect on a scale of 0 and no usability problems are found, so that the design that has been made, a decision support system can be built according to the design that has been made.

Keywords : Covid-19, Hospital, WISN, PROMETHEE II, Labor. 


\section{PENDAHULUAN}

Pada tahun 2020, seluruh dunia termasuk Indonesia telah mengalami wabah COVID-19. Virus ini tergolong baru dan memiliki tingkat penularan yang relatif cepat dengan tingkat kematian yang tinggi [1]. Wabah ini mempengaruhi banyak instansi di Indonesia, diantaranya pendidikan, pelayanan kesehatan, dan sektor - sektor industri. Salah satu instansi yang terdampak secara signifikan adalah pelayanan kesehatan [2]. Kasus COVID-19 pertama kali terkonfirmasi di Indonesia pada tanggal 2 Maret 2020, hingga saat ini kasus positif COVID-19 terus meningkat drastis dan mengakibatkan banyak rumah sakit kewalahan menangani lonjakan pasien yang terinfeksi [3]. Salah satu faktor penyebab terjadinya masalah tersebut adalah kurangnya tenaga kerja yang ada di dalam rumah sakit tersebut.

Kendala rumah sakit beragam diantaranya, perhitungan jumlah kebutuhan tenaga kerja yang ada di rumah sakit cukup sulit untuk dilakukan dan membutuhkan waktu yang cukup lama. Selain itu beban kerja yang selalu berubah-ubah terutama selama wabah ini berlangsung, untuk melakukan penerimaan tenaga kerja juga mempunyai masalah yang serupa, yaitu cukup sulit dan membutuhkan waktu yang cukup lama untuk menentukan tenaga kerja yang sesuai dengan kriteria yang dibutuhkan. Untuk itu penulis membuat sebuah sistem yang mampu melakukan perhitungan jumlah kebutuhan tenaga kerja dan melakukan pembobotan calon tenaga kerja secara otomatis. Metode yang digunakan untuk menghitung jumlah kebutuhan tenaga kerja adalah WISN (Workload Indicator Staff Need), sedangkan untuk menentukan pembobotan tenaga kerja menggunakan metode PROMETHEE II (The Preference Ranking Organization Method for Enrichment of Evaluations II). Pemilihan metode WISN disesuaikan dengan tingkat kebutuhan pada rumah sakit yang membutuhkan kemudahan dalam menentukan variasi kebutuhan tenaga kesehatan dalam berbagai tipe layanan kesehatan. Sedangkan metode PROMETHEE II dipilih berdasarkan dua perangkingan yakni perangkingan parsial dan perangkingan lengkap, untuk mendapatkan calon tenaga kerja terbaik [4]. Penelitian ini mengambil sampling salah satu rumah sakit di Surabaya yakni rumah sakit ibu dan anak Nur Ummi Numbi yang terdampak COID-19 [5].

\section{METODOLOGI PENELITIAN}

Pada penelitian ini, penulis menggunakan metode WISN (Workload Indicator Staff Need) untuk menghitung kebutuhan tenaga kerja pada rumah sakit, dan metode PROMETHEE II untuk melakukan pembobotan calon tenaga kerja, sebagai pendukung keputusan [6].

\subsection{Pengumpulan data dan Observasi}

Pengumpulan data dan observasi dilakukan peneliti dengan cara melakukan riset dan wawacara pada rumah sakit mengenai permasalahan, dan proses bisnis yang terjadi. Kemudian dilakukan analisa kebutuhan dan permodelan sistem penerimaan kebutuhan tenaga kerja pada rumah sakit [7].

\subsection{Perhitungan Kebutuhan Tenaga Kerja Metode WISN}

Terdapat 5 tahap dalam mekanisme perhitungan kebutuhan tenaga kerja. Yaitu menetapkan waktu kerja tersedia, menetapkan unit kerja, menyusun standar beban kerja, menyusun standar kelonggaran dan perhitungan tenaga per unit kerja [8]. Adapun langkahlangkah yang harus dilakukan pada metode WISN yaitu :

1. Menetapkan Waktu Kerja Tersedia.

Waktu kerja tersedia merupakan total waktu waktu satu tahun, yang terdiri dari total hari, minggu, jam, dan menit yang dibutuhkan tenaga kerja dalam bekerja maupun tidak bekerja. Perhitungan waktu berkerja dan tidak bekerja menghasilkan waktu kerja efektif.

2. Menyusun standar beban kerja

Standar beban kerja merupakan deskripsi uraian kegiatan tenaga kerja pada rumah sakit beserta waktu kegiatan yang dibutuhkan untuk menyelesaikan kegiatan tersebut. Uraian kegiatan mendeskripsikan kualitas, waktu, standar beban kerja, dan kebutuhan tenaga kerja.

3. Menyusun standar kelonggaran 
Standar kelonggaran merupakan uraian kegiatan yang dilakukan tenaga kerja di rumah sakit diluar tanggung jawab dalam pelayanan kesehatan. Uraian kegiatan mendeskripsikan waktu dalam satuan menit, jumlah waktu, faktor kelonggaran, dan standar kelonggaan.

4. Perhitungan kebutuhan tenaga kerja

Kebutuhan tenaga kerja merupakan total standar beban kerja dan standar kelonggaran, yang kemudian hasil perhitungan tersebut dibulatkan dengan bilangan yang paling mendekati. Untuk menghasilkan kebutuhan tenaga kerja pada unit yang telah ditentukan.

\subsection{Perhitungan Penerimaan Tenaga Kerja Metode PROMETHEE II}

Terdapat langkah-langkah yang harus dilakukan dalam metode PROMETHEE II, yaitu sebagai berikut [9]:

a. Menentukan Alternatif

Tahap ini dihasilkan berdasarkan data penerimaan calon tenaga kerja pada RSIA NUN, nantinya data tersebut digunakan sebagai salah satu variabel dalam pembobotan.

b. Menentukan kriteria

Tahap ini merupakan kriteria atau standar yang telah ditentukan RSIA NUN dalam melakukan penerimaan calon tenaga kerja.

c. Menentukan Nilai dan Menghitung Nilai preferensi

Tahap ini menentukan nilai data penilaian setiap alternatif pada setiap kriteria, yang kemudian dilanjutkan dengan melakukan perhitungan nilai preferensi.

d. Menghitung indeks preferensi

Berdasarkan hasil perhitungan nilai preferensi, yang telah dilakukan sebelumnya. Tahap selanjutkan dilakukan perhitungan untuk mencari nilai indeks preferensi

e. Menghihtung PROMETHEE I

Tahap ini adalah menghitung data menggunakan PROMETHEE I yaitu Leaving Flow merupakan nilai tertinggi dibanding nilai data lainnya dan Entering Flow merupakan nilai yang terendah lalu akan terjadi perankingan data-data alternatif.

f. Menghitung PROMETHEE II

Setelah menghitung PROMETHEE I, langkah terakhir adalah menghitung PROMETHEE II yang didapat dengan menghitung Net Flow yang didapatkan berdasarkan hasil pengurangan nilai leaving flow dengan nilai entering flow.

\subsection{Desain Sistem}

Desain sistem yang digunakan untuk membuat perancangan sistem pemenuhan tenaga kerja di rumah sakit pada penelitian ini, menggunakan diagram UML (Unified Modeling Language) yakni sebagai berikut [10].

\section{Use Case Diagram}

Usecase diagram digunakan untuk menggambarkan pengguna dan fitur-fitur apa saja yang tersedia, Use case diagram terdiri dari sebuah aktor dan interaksi yang dilakukannya, aktor tersebut dapat berupa manusia, perangkat keras, sistem lain, ataupun yang berinteraksi dengan sistem [11].

2. Diagram Aktifitas (Activity Diagram)

Activity Diagram digunakan untuk menunjukkan aktivitas sistem dalam bentuk kumpulan aksi-aksi, bagaimana masing-masing aksi tersebut dimulai, keputusan yang mungkin terjadi hingga berakhirnya aksi [12].

\subsection{Desain Antar Muka}

Desain antar muka (user interface) merupakan seperangkat alat atau elemen yang digunakan untuk menyatakan bahwa sebuah desain antar muka (user interface) dianggap baik apabila dapat berfungsi dengan baik, tidak hanya mempertimbangkan aspek estetik saja [13]. Desain antar muka digunakan untuk menggambarkan fitur-fitur yang telah dideskripsikan pada desain sistem pemenuhan tenaga kerja pada rumah sakit. 


\subsection{Metode Heuristic Evaluation}

Merupakan salah satu metode evaluasi usability untuk mengetahui sistem pemenuhan tenaga kerja yang telah dirancang dapat digunakan oleh pengguna serta mencapai tujuan tertentu dengan efektifitas, efisiensi dan kepuasan [14]. Adapun nilai severity rating berdasarkan Heuristic Evaluation antara lain [15]:

1. Visibility of system status yaitu suatu sistem dapat memberi informasi kepada pengguna terhadap situasi yang sedang terjadi dari feedback yang diberikan.

2. Match between system and the real world yaitu suatu sistem perlu menggunakan konsep dan bahasa yang dengan mudah dimengerti oleh user.

3. User control and freedom yaitu pencegahan kesalahan yang mungkin dilakukan oleh user, dan sistem perlu membuat menu untuk undo atau redo.

4. Consistency and standard yaitu konsistensi antarmuka pada sistem sesuai standar

5. Error prevention yaitu penanggulangan kesalahan yang dapat terjadi

6. Recognition rather than recall yaitu komponen pada sistem yang membuat user tidak perlu mengingat-ingat proses berikutnya

7. Flexibility and efficiency of use yaitu suatu komponen pada sistem yang bersifat efisien serta fleksibel untuk membuat user cepat dalam melakukan tugas

8. Aesthetic and minimalist design yaitu desain yang aesthetic tidak mengganggu user dalam menggunakan suatu sistem

9. Help users recognize, diagnose, and recover from errors yaitu pesan error dengan bahasa yang sederhana dan memberikan solusi kepada user

10. Help and documentation yaitu menyediakan fitur bantuan dan dokumentasi untuk membantu user dalam menggunakan sistem

Setelah dilakukan pengujian pada pengguna sistem pemenuhan tenaga kerja pada rumah sakit, yakni HRD, dan kepala direktur. Dilakukan perhitungan pada evaluasi Heuristic evaluation menggunakan persamaan :

$$
\sum H_{x}=(0 * x)+(1 * x)+(2 * x)+(3 * x)+(4 * x)+\cdots
$$

Keterangan :

$\sum H_{x}$ : jumlah skor rating dari sub aspek usability dalam setiap aspek usability (H1 - H10)

$x$ : poin usability, bernilai 1 sampai 0

Untuk menghasilkan nilai severity rating dari masing-masing aspek usability menggunakan persamaan

$$
s v=\sum \frac{H_{x}}{n}
$$

Keterangan :

$s v$ : Hasil severity rating dalam satu aspek usability

$n$ : Banyaknya sub aspek usability dalam setiap aspek usability

Dengan skala nilai severity rating :

Skala 0 : Tidak ditemukan adanya permasalahan atau kekurangan pada usability

Skala 1 : Kategori cosmetic problem, permasalahan tidak perlu diperbaiki kecuali waktu pengerjaan proyek masih tersedia.

Skala 2 : Kategori minor usability problem, permasalahan kegunaan kecil, perbaikan ini diberikan prioritas yang rendah.

Skala 3 : Kategori major usability problem, permasalahan kegunaan utama, perbaikan penting dilakukan, maka dari itu diberikan prioritas tinggi.

Skala 4 : Kategori usability catastrophe, permasalahan perbaikan ini harus dilakukan sebelum produk diluncurkan. 


\section{PENGUJIAN DAN PEMBAHASAN}

Untuk menghasilkan perancangan sistem pemenuhan tenaga kerja pada rumah sakit, yang sesuai dengan tujuan, penulis melakukan pengujian usability dengan metode heuristic evaluation. Pembahasan perancangan sistem pemenuhan tenaga kerja di rumah sakit pada penelitian ini adalah sebagai berikut:

\subsection{Pengumpulan Data dan Observasi}

Pengumpulan data dan observasi dilakukan penulis dengan cara wawancara, menghasilkan alur proses bisnis berdasarkan data yang telah diperoleh dari rumah sakit yakni data beban kerja WISN, alur penerimaan tenaga kerja dan persyaratan tenaga kerja. Terdapat 3 aktor pada alur proses bisnis yakni Kepala Direktur, HRD dan calon tenaga kerja. Proses bisnis dimulai dari HRD memasukkan data unit dan workload, hingga Kepala Direktur melakukan konfirmasi penerimaan tenaga kerja.

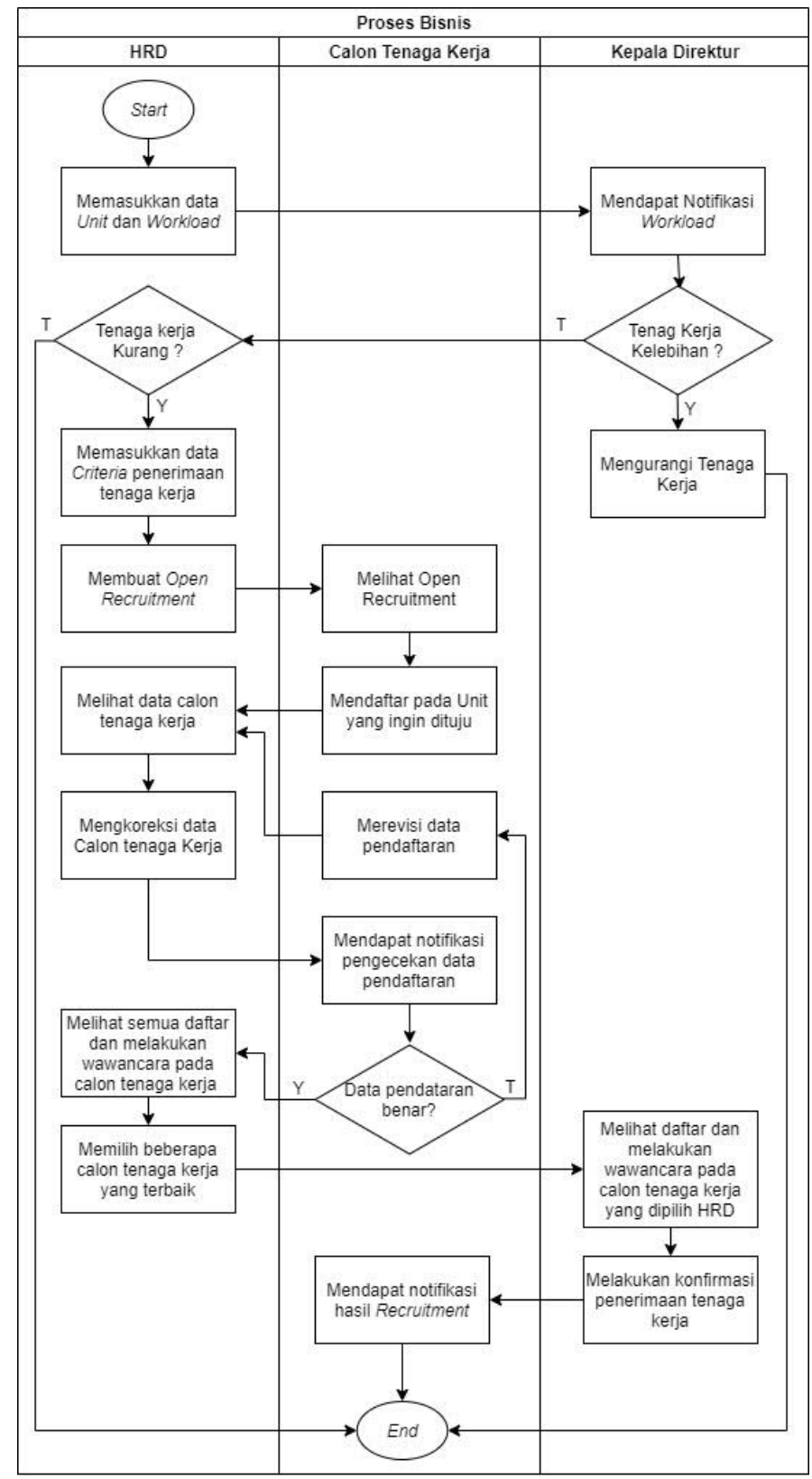

Gambar 1. Proses Bisnis

Pada gambar 1 merupakan Flow Chart diagram proses bisnis yang menunjukkan bahwa setelah HRD memasukkan data unit dan workload, HRD memasukkan data kriteria penerimaan 
tenaga kerja dan membuat open recruitment apabila terjadi kekurangan tenaga kerja. Kemudian calon tenaga kerja dapat melihat open recruitment dan mendaftar pada unit yang ingin dituju. HRD mengkoreksi data calon tenaga kerja, apabila data terdapat kekeliruan dapat segera diperbaiki oleh calon tenaga kerja tersebut. Sedangkan apabila data pendaftaran tidak terdapat kekeliruan, maka HRD dapat melakukan wawancara pada calon tenaga kerja tersebut.

Selanjutnya HRD melakukan pemilihan calon tenaga kerja yang terbaik, kemudian kepala direktur melihat daftar calon tenaga kerja dan melakukan wawancara kepada calon tenaga kerja yang sudah dipilih sebelumnya. Terakhir kepala direktur dapat melakukan konfirmasi penerimaan tenaga kerja, kemudian calon tenaga kerja mendapatkan notifikasi hasil pendaftaran.

\subsection{Desain Sistem}

Desain sistem yang digunakan untuk merancang pemenuhan tenaga kerja di rumah sakit, menggunakan diagram UML.

a. Use case diagram

Permodelan use case diagram bertujuan untuk mendetailkan fitur yang tersedia pada sistem. Terdapat 16 fitur pada sistem pemenuhan tenaga kerja dirumah sakit, dengan 3 pengguna yakni HRD, Kepala Direktur dan Calon Tenaga Kerja.

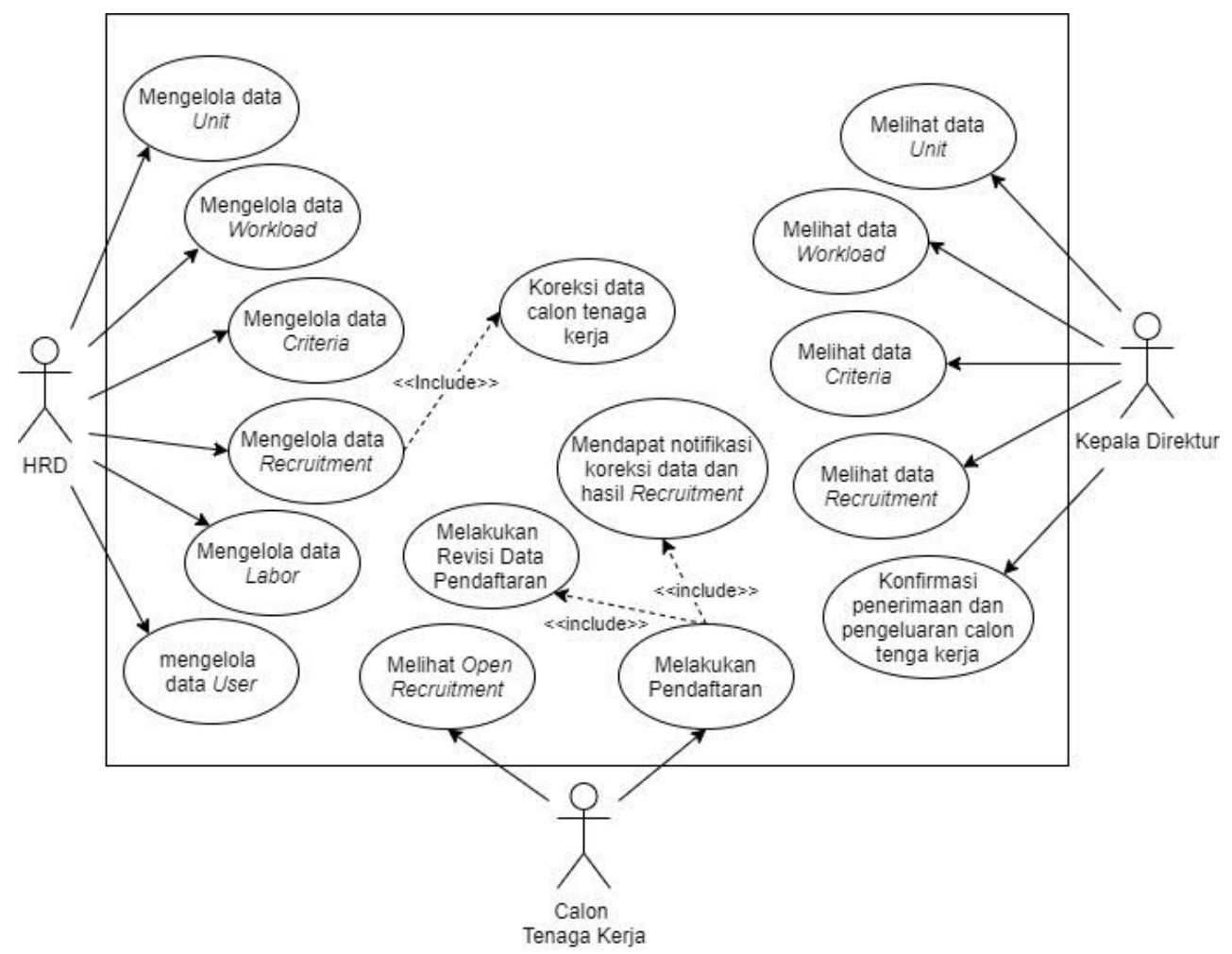

Gambar 2. Use case Diagram

Pada gambar 2 usecase diagram, menunjukkan bawah tugas HRD adalah mengolah data unit, workload, criteria, recruitment, labor, dan user. Selain itu HRD juga bertugas mengkoreksi data calon tenaga kerja yang telah melakukan pendaftaran. Kepala Direktur dapat melihat data dan bertugas untuk melakukan konfirmasi penerimaan tenaga kerja yang akan diterima. Sedangkan calon tenaga kerja dapat melihat dan melakukan pendaftaran yang tersedia pada unit tersebut, hingga mendapatkan notifikasi koreksi dan hasil pendaftaran. Apabila terdapat kesalahan pada data pendaftaran calon tenaga kerja dapat melakukan perbaikan data pendaftaran.

b. Activity diagram

Permodelan activity diagram bertujuan untuk mendeskripsikan proses berjalannya sebuah fitur, yang telah dimodelkan use case diagram. Sehingga dapat menghasilkan sebuah sistem yang baik dan sesuai dengan tujuan. 

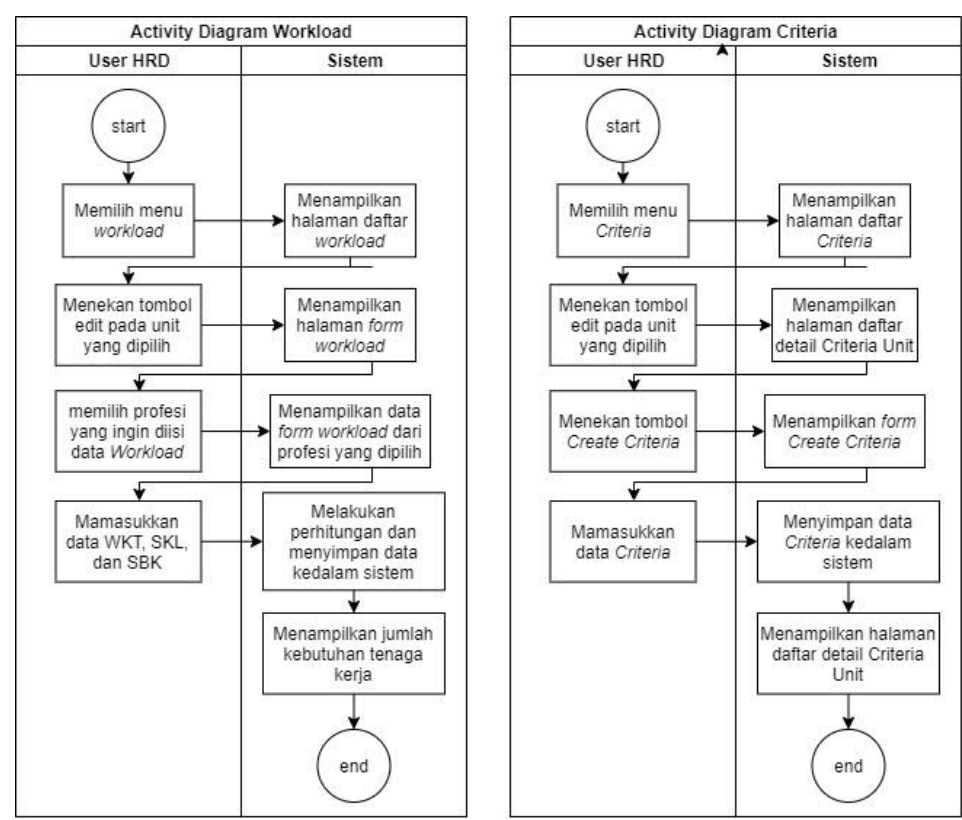

Gambar 3. Activity Diagram

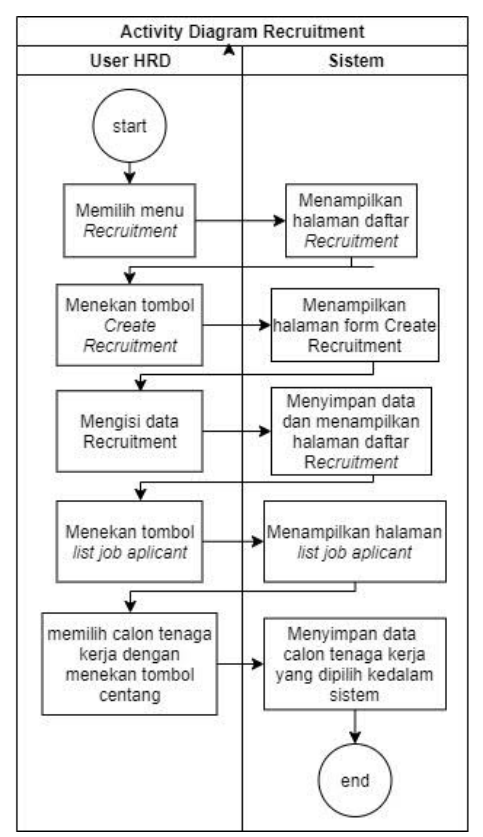

Pada gambar 3 activity diagram, merupakan Alur HRD untuk mengolah data Workload, Criteria dan Recruitment pada sistem. Pada activity diagram workload dijelaskan bahwa HRD harus memilih menu workload terlebih dahulu. Sistem akan menampilkan halaman daftar workload, kemudian HRD dapat menekan tombol edit untuk memasukkan data WKT, SKL, dan SBK pada unit yang dipilih. Setelah data dimasukkan, sistem akan melakukan perhitungan kebutuhan tenaga kerja serta menyimpan dan menampilkan hasil perhitungan.

Pada activity diagram criteria HRD memilih menu criteria, kemudian menekan tombol edit pada unit yang dipilih. Sistem akan menampilkan halaman daftar detail criteria pada unit tersebut. HRD dapat menekan tombol criteria yang terdapat pada halaman daftar detail criteria unit tersebut untuk memasukkan data criteria. Setelah data dimasukkan, sistem akan menyimpan data dan menampilkan data pada halaman daftar detail criteria unit.

Pada activity diagram recruitment, HRD memilih menu recruitment kemudian sistem akan menampilkan halaman daftar recruitment. HRD dapat menekan tombol create recruitment untuk memasukkan data recruitment. Setelah data dimasukkan, sistem akan menyimpan data recruitment. Setelah data dimasukkan, HRD dapat melihat daftar calon tenaga kerja yang telah mendaftar dengan menekan tombol list job applicant pada halaman daftar recruitment. Sistem akan menampilkan daftar calon tenaga kerja yang telah mendaftar beserta urutan yang telah dihitung berdasarkan criteria yang telah dimasukkan sebelumnya. Langkah terakhir HRD dapat memilih calon tenaga kerja yang ingin diterima.

\subsection{Perancangan}

Perancangan sistem pemenuhan tenaga kerja dirumah sakit, merupakan tampilan dari aplikasi yang akan dibuat. Pada bagian ini, penulis hanya menjelaskan desain antar muka untuk HRD yaitu sebagai berikut:

\section{Halaman Dashboard}

Halaman dashboard bertujuan untuk memudahkan pengguna mengetahui informasi jumlah kebutuhan tenaga kerja pada setiap unit. Dan juga jumlah calon tenaga kerja yang telah mendaftar apabila unit membuka perekrutan tenaga kerja. Halaman dashboard akan menampilkan grafik berupa angka dari hasil perhitungan pada data setiap unit. 


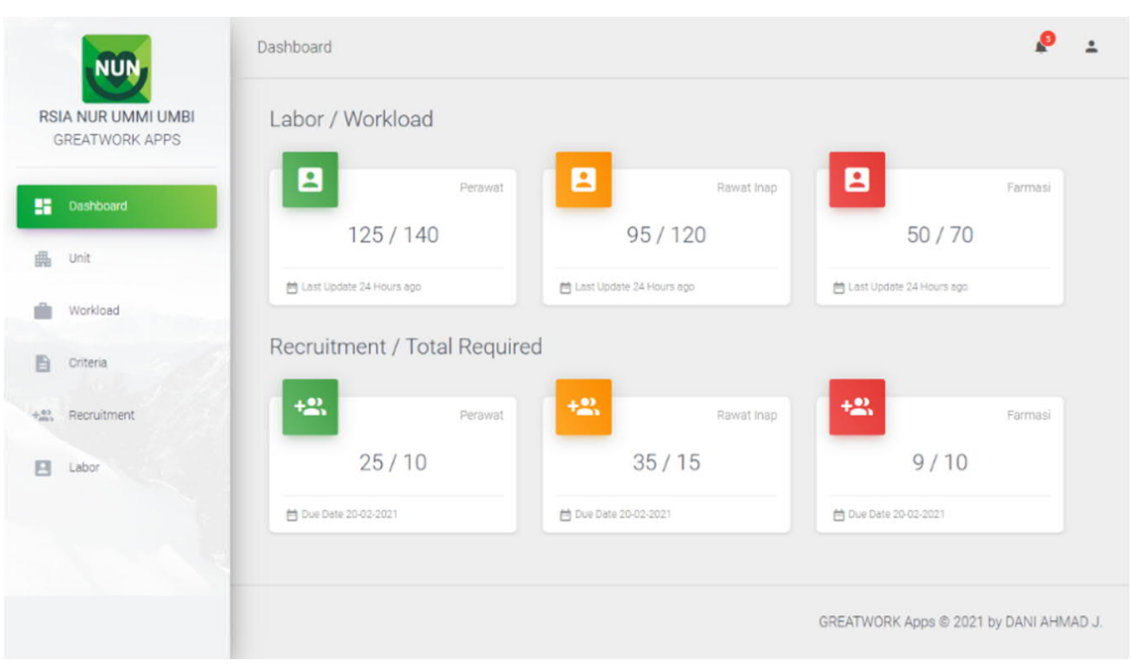

Gambar 4. Halaman Dashboard

Pada gambar 4 halaman dashboard, merupakan contoh grafik berupa angka dari hasil perhitungan pada setiap unit yang tertera pada halaman dashboard berdasarkan data yang telah dimasukkan sebelumnya. Grafik yang paling atas adalah jumlah tenaga kerja yang ada saat ini dibandingkan dengan jumlah kebutuhan tenaga kerja pada setiap unit. Sehingga pengguna dapat mengetahui dengan mudah apabila terdapat kekurangan pada unit tersebut. Kemudian pada grafik angka selanjutnya adalah jumlah tenaga kerja yang telah mendaftar dibandingkan dengan jumlah tenaga kerja yang ingin diterima. Sehingga pengguna dapat mengetahui dengan mudah apabila jumlah tenaga kerja yang mendaftar telah melewati batas jumlah yang ingin diterima. Pengguna juga dapat menghentikan recruitment apabila bersadarkan grafik angka yang telah dilihat sebelumnya telah mencapai batas yang diinginkan.

\section{Halaman Workload}

Halaman workload, berisikan daftar kebutuhan tenaga kerja pada setiap unit yang telah diinputkan sebelumnya. Yakni nama unit, jumlah tenaga kerja pada saat ini, jumlah tenaga kerja yang dibutuhkan, dan status pada masing-masing unit. Status tersebut yakni kelebihan tenaga kerja, kekurangan tenaga kerja, tenaga kerja telah terpenuhi dan belum terisi apabila data belum dimasukkan. Status didapatkan berdasarkan data yang telah dimasukkan pada halaman set workload dengan menekan tombol ber icon pensil.

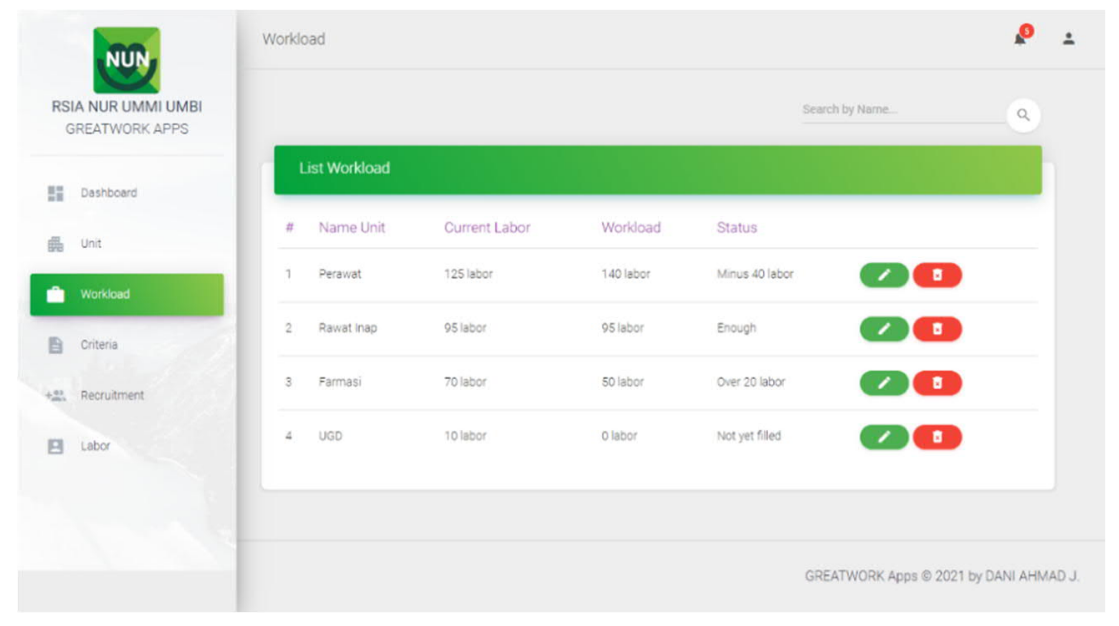

Gambar 5. Halaman Workload

Pada gambar 5, Halaman set workload terdapat icon pensil dan sampah. Yang mana pada icon pensil pada saat di klik menampilkan inputan data workload, yang terdiri dari waktu kerja tersedia, standar kelonggaran, standar beban kerja. Sedangkan icon sampah digunakan untuk menghapus data workload yang telah diinputkan sebelumnya. 
a. Waktu Kerja Tersedia

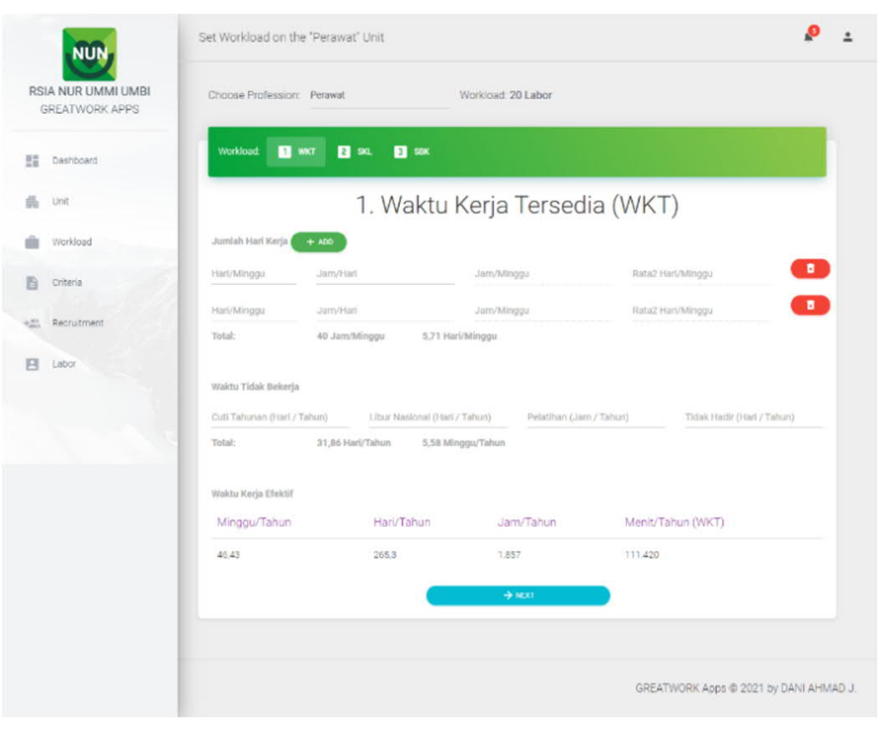

Gambar 6. Form Waktu Kerja Tersedia

Gambar 6 merupakan waktu kerja tersedia, yang digunakan untuk menghitung waktu kerja tersedia pada masing-masing unit selama satu tahun. Untuk memasukkan data pada halaman pengguna dapat memilih profesi pada unit yang ingin dituju kemudian dapat memasukkan data jam kerja dan waktu tidak bekerja. Perhitungan dilakukan berdasarkan total jam aktif bekerja dikurangi total waktu tidak bekerja, sehingga sistem dapat menghasilkan jumlah waktu kerja tersedia (WKT).

b. Standar Kelonggaran

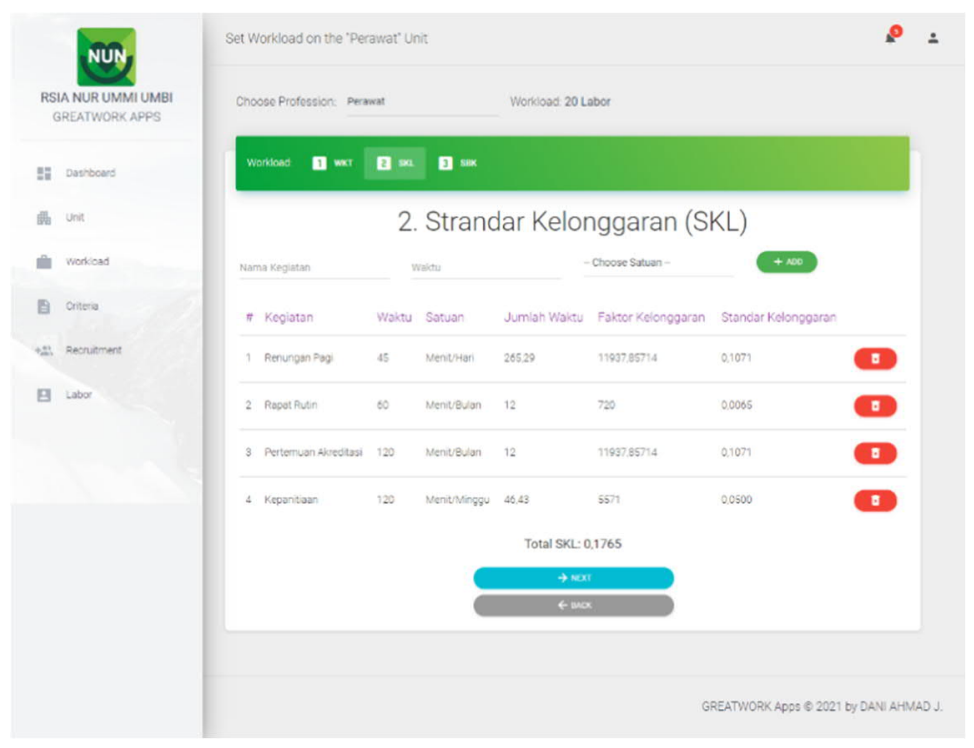

Gambar 7. Standart Kelonggaran

Gambar 7 merupakan tampilan standar kelonggaran, yang berisikan standar aktifitas untuk kegiatan pendukung dan tambahan yang akan dilakukan pada profesi di unit tersebut. Halaman ini bertujuan untuk menghitung total standar kelonggaran, dengan memasukkan data yakni nama kegiatan, waktu, dan satuan waktu. Kemudian sistem akan menghitung Faktor Kelonggaran dan Standar Kelonggaran pada setiap kegiatan. Yang kemudian sistem menjumlahkan seluruh standar kelonggaran untuk mencari total standar kelonggaran. 
c. Standar Bedan Kerja

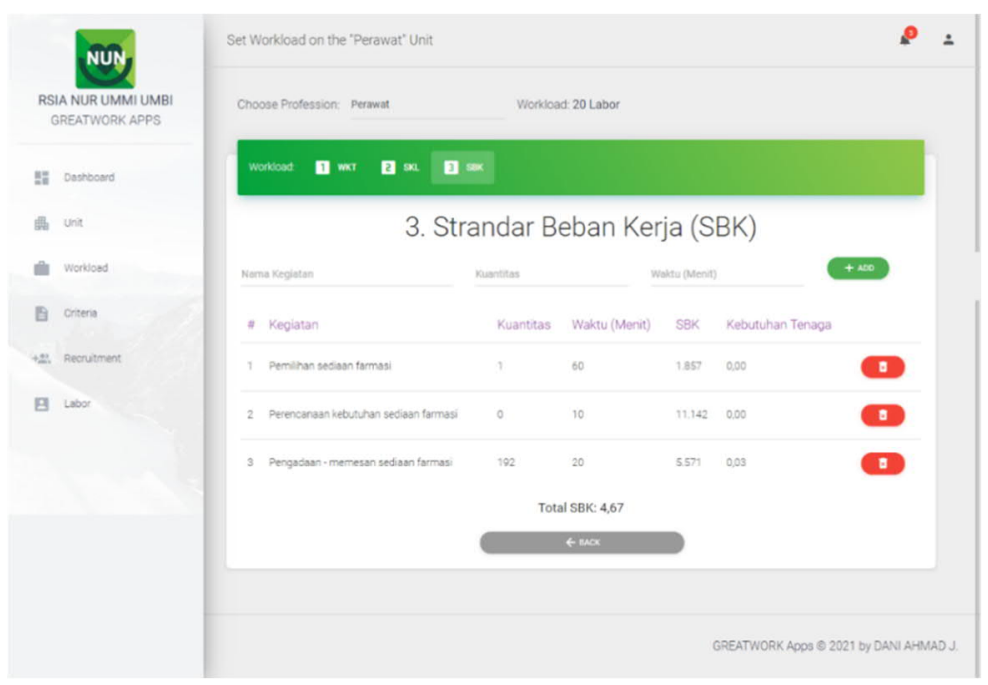

Gambar 8. Standart Beban Kerja

Gambar 8 merupakan tampilan standar beban kerja, yang merupakan jumlah aktifitas yang akan dilakukan tenaga kerja dalam satu tahun. Halaman ini digunakan untuk menghitung total beban kerja dengan masukkan data beban kerja pada masing-masing unit, berdasarkan kuantitas dan waktu yang dibutuhkan untuk melakukan kegiatan tersebut. Perhitungan standar beban kerja didapatkan berdasarkan inputan standar kelonggaran.

3. Halaman Criteria

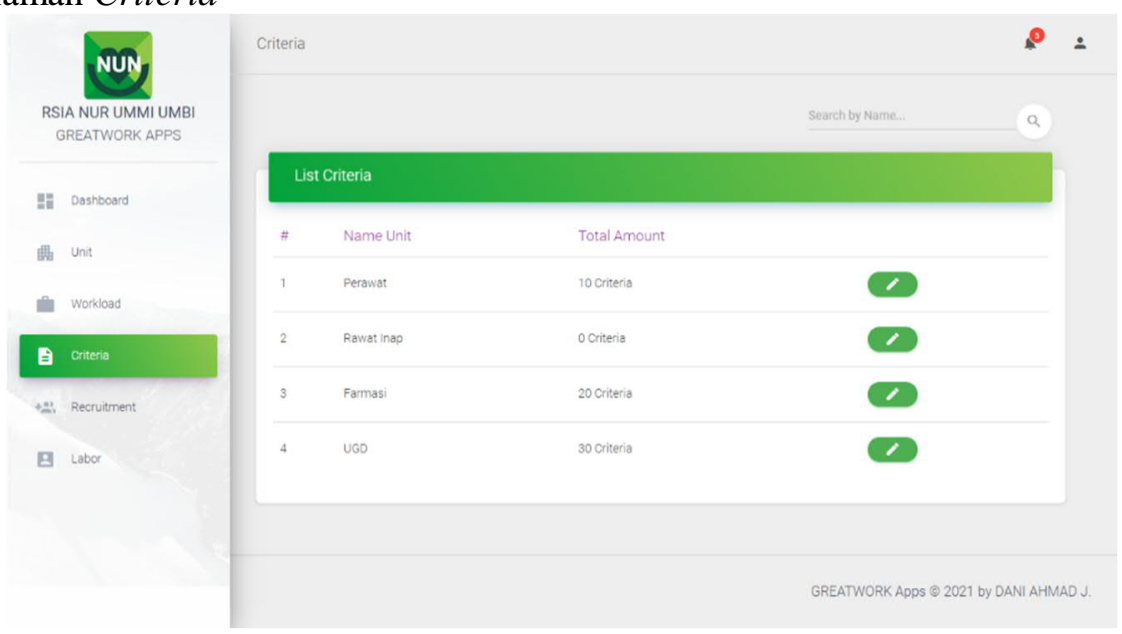

Gambar 9. Halaman Criteria

Gambar 9 Halaman criteria merupakan halaman yang menampilkan daftar criteria pada setiap unit untuk melakukan perekrutan tenaga kerja pada rumah sakit. HRD dapat memilih profesi yang ingin dipilih sebelum memasukkan data. Ada 4 tipe kriteria yang dapat dipilih HRD untuk membuat form kriteria, diantaranya Multiple Choise berupa pilihan ganda, Checkbox berupa kotak centang, dan Essay berupa tulisan. Sedangkan Private merupakan form yang tidak akan ditampilkan oleh sistem kepada calon tenaga kerja, namun akan secara langsung ditampilkan dan dinilai oleh HRD. 
4. Halaman Recruitment

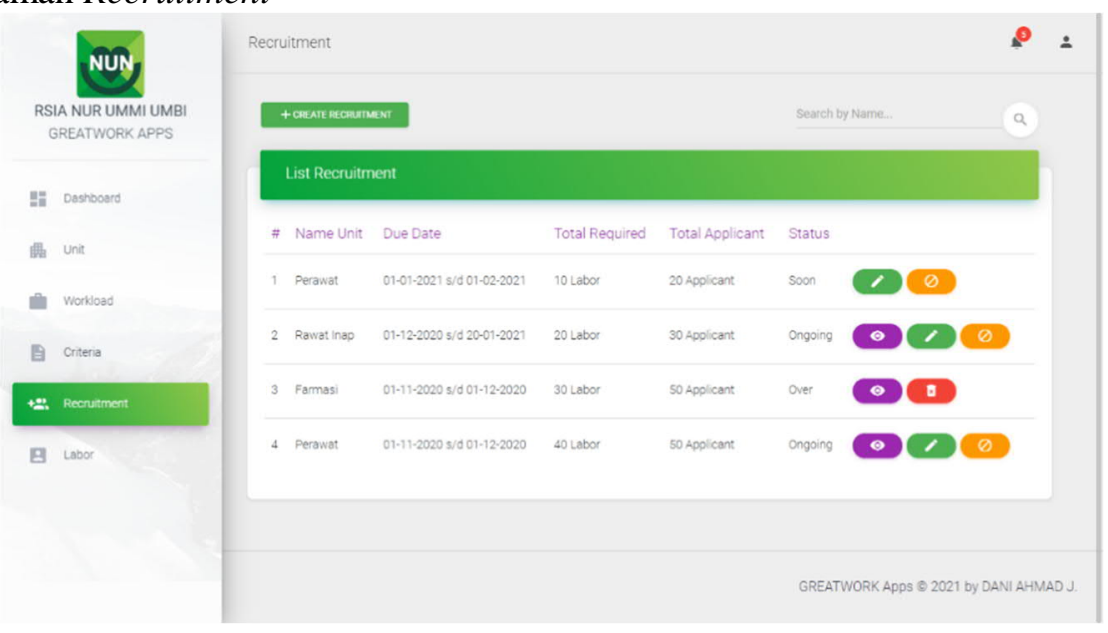

Gambar 10. Halaman Recruitment

Gambar 10 halaman recruitment merupakan halaman yang menampilkan daftar recruitment yang telah dibuat. Daftar recruitment berisikan nama unit, batas waktu recruitment, total jumlah yang dibutuhkan, total jumlah calon tenaga kerja yang telah mendaftar dan status recruitment. Status yang terdapat pada recruitment antara lain soon ketika batas waktu recruitment belum dimulai, ongoing ketika batas waktu telah berlangsung, serta done ketika batas waktu telah selesai. Pada halaman ini pengguna dapat menekan tombol create recruitment yang berada dibagian atas halaman untuk membuat recruitment.

5. Halaman List Job Applicant

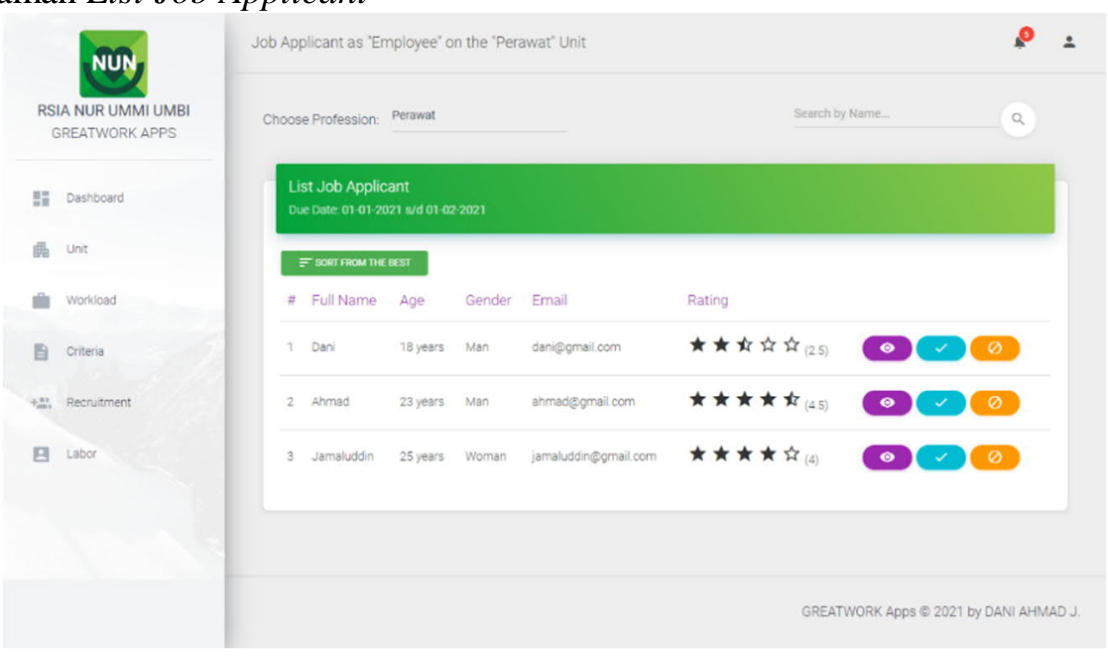

Gambar 11. Halaman List Job Applicant

Gambar 11 halaman List Job Applicant, yang akan ditampilkan ketika pengguna memilih tombol dengan simbol mata pada halaman recruitment. Halaman ini akan menampilkan daftar calon tenaga kerja yang telah mendaftar pada recruitment tersebut. Daftar tersebut berisikan Nama, Umur, Jenis Kelamin, Email dan peringkat calon tenaga kerja. HRD memilih profesi yang dinginkan pada bagian atas halaman terlebih dahulu, sehingga sistem akan menampilkan data yang ada pada profesi tersebut. HRD dapat menekan tombol Sort From The Best untuk mengurutkan daftar calon tenaga kerja dari yang terbaik hingga terendah. Untuk melihat dan mengkoreksi detail data calon tenaga kerja HRD dapat menekan tombol dengan simbol mata yang ada pada daftar calon tenaga kerja. Kemudian langkah terakhir HRD dapat memilih calon tenaga kerja yang akan diterima dengan menekan tombol dengan simbol centang. 


\subsection{Hasil Pengujian Heuristic Evaluation}

Berikut merupakan hasil pengujian usability dengan metode heuristic evaluation yang melibatkan para pengguna sistem pemenuhan tenaga kerja pada rumah sakit.

Tabel 1. Hasil Pengujian Pengguna Sistem Pemenuhan Tenaga Kerja

\begin{tabular}{|l|c|c|}
\hline \multicolumn{1}{|c|}{ Aspek } & $\begin{array}{c}\text { Nilai Masing- } \\
\text { masing Aspek }\end{array}$ & $\begin{array}{c}\text { Nilai } \\
\text { Pembulatan }\end{array}$ \\
\hline Visibility of system status & 0.2 & 0 \\
\hline Match between system and the real world & 0.3 & 0 \\
\hline User control and freedom & 0 & 0 \\
\hline Consistency and standard & 0 & 0 \\
\hline Error prevention & 0.1 & 0 \\
\hline Recognition rather than recall & 0.3 & 0 \\
\hline Flexibility and efficiency of use & 0.1 & 0 \\
\hline Aesthetic and minimalist design & 0.8 & 1 \\
\hline Help users recognize, diagnose, and recover from errors & 0.6 & 1 \\
\hline Help and documentation & 0.2 & 0 \\
\hline Nilai Rata-rata Severity Rating & & 0 \\
\hline
\end{tabular}

Pada tabel 1 merupakan hasil dari pengujian usability dengan metode Heuristic Evaluation dari responden pengguna sistem pemenuhan tenaga kerja nantinya. Nilai rata-rata severity rating yang diperoleh yaitu 0.2 yang dibulatkan menjadi skala 0 , artinya tidak ditemukan adanya permasalahan pada usability.

\section{KESIMPULAN}

Hasil pengujian perancangan sistem pemenuhan kebutuhan pada rumah sakit menggunakan metode Heuristic Evaluation. Pada pengguna aplikasi yakni HRD dan kepala direktur, mendapatkan nilai rata-rata 0 , yang artinya tidak ditemukan permasalahan pada usability aplikasi apabila dilakukan pengembangan hingga tahap implementasi. Seluruh proses perancangan menggunakan diagram UML, dan menghasilkan 8 buah tampilan menu dengan 3 pengguna sistem. Sedangkan pemilihan metode WISN dan PROMETHEE II telah sesuai dengan tingkat kebutuhan dan kondisi pada rumah sakit. Untuk dijadikan sistem pendukung keputusan pemilihan tenaga kerja guna mempercepat proses pelayanan kesehatan pada RSIA NUN.

\section{Daftar Pustaka}

[1] A. Susilo et al., "Coronavirus Disease 2019: Tinjauan Literatur Terkini," J. Penyakit Dalam Indones., vol. 7, no. 1, p. 45, 2020, doi: 10.7454/jpdi.v7i1.415.

[2] I. Ridwan and F. Saftarina, "Pelayanan Fasilitas Kesehatan: Faktor Kepuasan dan Loyalitas Pasien," J. Major., vol. 4, no. 9, pp. 20-26, 2015, [Online]. Available: http://juke.kedokteran.unila.ac.id/index.php/majority/article/view/1403.

[3] I. Dhamanti, "Mengapa Rumah Sakit Kewalahan Hadapi Corona dan Apa Dampaknya?," Kompas.com, https://www.kompas.com/sains/read/2020/05/08/130400523/mengapa-rumah-sakitkewalahan-hadapi-corona-dan-apa-dampaknya-?page=all (accessed Nov. 01, 2020).

[4] M. Wafi, R. Setya Perdana, and W. Kurniawan, "Implementasi Metode Promethee II untuk Menentukan Pemenang Tender Proyek (Studi Kasus: Dinas Perhubungan dan LLAJ Provinsi Jawa Timur)," J. Pengemb. Teknol. Inf. dan Ilmu Komput., vol. 1, no. 11, pp. 1224-1231, 2017, [Online]. Available: http://j-ptiik.ub.ac.id.

[5] RSIA NUN, "RSIA NUN - Sahabat Terbaik Keluarga Anda." http://nun.co.id/ (accessed Aug. 10, 2021).

[6] L. Lisnawaty, F. Dina, and D. O. Sihombing, "Sistem Pendukung Keputusan Pemilihan Calon Tenaga Kerja di Kota Pontianak Dengan Metode Simple Additive Weighting (SAW)," J. Pilar Nusa Mandiri, vol. 14, no. 2, pp. 201-208, 2018, [Online]. Available: http://ejournal.nusamandiri.ac.id/index.php/pilar/article/view/40/35.

[7] I. N. Rachmawati, "Pengumpulan Data Dalam Penelitian Kualitatif: Wawancara," $J$. 
Keperawatan Indones., vol. 11, no. 1, pp. 35-40, 2007.

[8] Kemenkes RI, "Keputusan Menteri Kesehatan Republik Indonesia Tentang Pedoman Penyusunan Perencanaan Sumber Daya Manusia," pp. 1-53, 2004.

[9] F. Adelia, D. Wahyuli, T. I. Sari, and A. P. Windarto, "Analisis Promethee II Pada Faktor Penyebab Mahasiswa Sulit Menemukan Judul Artikel Ilmiah,” J. Ilm. KOMPUTASI, vol. 17, no. 2, pp. 131-136, 2018.

[10] P. Sulistyorini, "Pemodelan Visual dengan Menggunakan UML dan Rational Rose," $J$. Teknol. Inf. Din. Vol., vol. XIV, no. 1, pp. 23-29, 2009.

[11] T. B. Kurniawan, "Perancangan Sistem Aplikasi Pemesanan Makanan Dan Minuman Pada Cafetaria No Caffe Di Tanjung Balai Karimun Menggunakan Bahasa Pemograman PHP dan MySQL,” J. TIKAR, vol. 1, no. 2, pp. 192-206, 2020.

[12] Suendri, "Implementasi Diagram UML (Unified Modelling Language) Pada Perancangan Sistem Informasi Remunerasi Dosen Dengan Database Oracle (Studi Kasus: UIN Sumatera Utara Medan)," Algoritm. J. Ilmu Komput. dan Inform., vol. 3, no. 1, pp. 1-9, 2018.

[13] W. Wibwawanto and R. Nugrahani, "Desain Antarmuka (User Interface) Pada Game Edukasi,” J. Imajin., vol. XII, no. 2, pp. 57-64, 2018, [Online]. Available: https://journal.unnes.ac.id/nju/index.php/imajinasi/article/view/17472.

[14] S. V. N. Fitri, O. Juwita, and T. Dharmawan, "Analisis User Interface Terhadap Website Akta Online Banyuwangi Menggunakan Metode Heuristic Evaluation," INFORMAL Informatics J., vol. 4, no. 3, p. 103, 2020, doi: 10.19184/isj.v4i3.12594.

[15] I. G. Ayu, A. Diah, I. P. A. Bayupati, and I. M. S. Putra, "Analisis Usability Aplikasi iBadung Menggunakan Heuristic Evaluation Method," J. Ilm. Merpati (Menara Penelit. Akad. Teknol. Informasi), vol. 8, no. 2, pp. 89-100, 2020. 